\title{
PENGALAMAN PEREMPUAN SETELAH MENJALANI TERAPI KANKER SERVIKS
}

\author{
Erfina $^{1,2^{*}}$, Yati Afiyanti ${ }^{3}$ Imami Nur Rachmawati ${ }^{3}$ \\ 1. Program Studi Ilmu Keperawatan Fakuktas Kedokteran Universitas Hasanuddin, Makasar 90245, Indonesia \\ 2. Program Studi Magister Fakultas Ilmu Keperawatan Universitas Indonesia, Depok 16424, Indonesia \\ 3. Fakultas Ilmu Keperawatan Universitas Indonesia, Depok 16424, Indonesia \\ *Email: ns_erfina@yahoo.co.id
}

\begin{abstract}
Abstrak
Kanker serviks merupakan salah satu keganasan pada sistem reproduksi perempuan. Tujuan penelitian ini adalah mengungkap makna dari pengalaman perempuan setelah menjalani terapi kanker serviks. Penelitian kualitatif ini dilakukan dengan menggunakan metode fenomenologi. Delapan orang partisipan yang dipilih secara purposive sampling di poliklinik RSX Jakarta. Penelitian ini mengidentifikasi lima tema yang menggambarkan makna pengalaman perempuan setelah menjalani terapi kanker serviks yaitu berbagai dampak setelah menjalani terapi, adaptasi untuk mengurangi keluhan fisik setelah terapi, harapan terhadap kehidupan setelah menjalani terapi, dukungan sosial, dan persepsi terhadap pelayanan kesehatan yang diperoleh. Berdasarkan hasil penelitian ini diharapkan perawat meningkatkan pelayanan keperawatan bagi perempuan bukan saja pada selama sakit dan menjalani terapi, tetapi juga setelah menjalani terapi kanker serviks.
\end{abstract}

Kata kunci: kanker serviks, pengalaman setelah terapi

Abstract

Cervical cancer is one of the malignancies in the female reproductive system. The aim of this research is to reveal the meaning of the experiences of women after cervical cancer therapy. This qualitative research was conducted using phenomenological methods. Eight participants were recruited by purposive sampling in the clinic of obstetric and gynecology at $X$ hospital Jakarta. This study identified five themes that describe the meaning of experiences of women after cervical cancer therapy are the adverse effects after therapy, adaptation to reduce physical complaints after therapy, the hope of life after therapy, social support, and perception of health care. This research's findings suggest that nurses are needed to improve nursing services for women not only on illness and therapy, but also after cervical cancer therapy.

Keywords: cervical cancer, experience after therapy

\section{Pendahuluan}

Kanker serviks merupakan salah satu gangguan pada sistem reproduksi perempuan dan tumor ganas kedua yang paling tinggi angka kejadiannya di dunia (Castilaw \& Wittet, 2007). Di Indonesia diperkirakan ditemukan 40.000 kasus baru kanker serviks setiap tahun ("Bahaya Kanker Serviks", 2009). Kanker serviks lebih banyak terdiagnosa pada stadium lanjut dan membutuhkan beberapa kombinasi terapi modalitas seperti pembedahan, radioterapi, dan kemoterapi (Castilaw \& Wittet, 2007; Otto, 2001).

Efek samping setelah pengobatan ini dapat menyebabkan perubahan pada fisik, psikologis maupun sosial (Vaz, et al., 2007). Penelitian yang dilakukan oleh Frumovitz, et al. (2005) meng- ungkapkan pasien kanker serviks yang memperoleh radioterapi mengalami gangguan fungsi seksual. Respon psi- kologis berupa ketakutan terhadap kekambuhan penyakit atau metastasis penyakit merupakan respon perempuan yang telah menjalani kanker serviks (Hobbs, 2008; McCorkle, et al., 1996).

Perubahan sosial juga dapat terjadi setelah perempuan menjalani terapi kanker serviks. Perempuan yang telah menjalani terapi kanker serviks akan dihadapkan pada isu keterbatasan dalam melakukan aktivitas akibat perubahan fisik (Anderson \& Lutgendorf, 1997; Otto, 2001).

Beberapa penelitian tentang dampak kanker serviks telah dilakukan termasuk tentang kualitas hidup. 
Namun demikian, penelitian tersebut lebih banyak dilakukan pada perempuan saat terdiagnosa kanker serviks bukan setelah menjalani terapi kanker serviks. Adapun pertanyaan penelitian ini adalah bagaimana makna dari pengalaman perempuan setelah menjalani terapi kanker serviks.

\section{Metode}

Penelitian ini menggunakan metode kualitatif dengan pendekatan fenomenologi yang bertujuan untuk menggali makna pengalaman perempuan setelah menjalani terapi kanker serviks. Strategi pengumpulan data yang digunakan dalam penelitian ini adalah wawancara mendalam dan catatan lapangan. Wawancara mendalam (In depth interview) untuk mengeskplorasi secara mendalam makna pengalaman perempuan setelah menjalani terapi kanker serviks.

Analisa data pada penelitian ini berdasarkan tahap analisis data menurut Colaizzi (1978, dalam Streubert \& Carpenter, 1999). Data rekaman hasil wawancara diubah dalam bentuk tertulis (transkrip), kemudian diidentifikasi kata kunci, menggabungkan kata kunci yang sama dalam bentuk kategori, menentukan subsub tema, kemudian tema-tema potensial, melakukan validasi ke partisipan dan menentukan tema akhir penelitian.

\section{Hasil}

\section{Karakteristik Partisipan}

Perempuan yang telah selesai menjalani terapi kanker serviks delapan orang terlibat dalam penelitian ini. Usia mereka bervariasi antara 29 sampai 46 tahun. Sebagian besar mempunyai pendidikan rendah yaitu SD dan SMP, dan dua orang partisipan mengaku tamatan SMEA dan Madrasah Aliyah. Seluruh partisipan beragama Islam dan berasal dari suku bangsa Jawa, Sunda, dan Betawi.

Sebagian besar partisipan adalah ibu rumah tangga, satu orang bekerja sebagai tukang ojek dan satu orang sebagai pegawai pabrik. Partisipan sebagian besar mulai terdiagnosa pada Oktober 2009 dan Maret 2010 dan didiagnosa pada stadium IIIB, dua partisipan pada stadium IIB dan dua partisipan pada stadium IB. Sebagian besar telah selesai menjalani terapi kanker serviks sejak satu bulan yang lalu saat penelitian.

Terapi yang telah dijalani berupa radioterapi, kemoterapi, dan pembedahan. Mengenai status pernikahan, dua partisipan mengaku menikah tiga kali, tiga partisipan menikah dua kali, dua partisipan menikah satu kali, dan satu partisipan berstatus janda.

\section{Berbagai Dampak setelah Menjalani Terapi Kanker Serviks}

Sebagian besar partisipan mendapatkan terapi kombinasi dari radioterapi, kemoterapi, dan histerektomi. Terapi ini menimbulkan dampak pada keluhan fisik seperti gangguan pada organ seksual dan gangguan pada organ yang lainnya. Gangguan organ seksual diungkapkan oleh sebagian besar partisipan berupa atropi vagina dan disparaneu. Berikut ini kutipan dari hasil wawancara dengan partisipan:

"sebelum sakit mah biasa, ngga mentok juga, tapi sekarang beda....terasa lebih pendek bu...”(P2).

Gangguan organ lainnya diungkapkan berupa gangguan kulit, gangguan pencernaan, kelelahan, dan gangguan eliminasi. Berikut ungkapan dari partisipan:

“....kemarin-kemarin malah kulit sempat lecet, basah karena kena air, sekarang mah dah sembuh Cuma belang-belang aja nih bagian kemaluan saya (P5).

Selain keluhan fisik, partisipan juga mengungkapkan dampak pada psikologis setelah menjalani terapi berupa ketidakpastian tentang kekambuhan dan respon terhadap keluhan fisik setelah menjalani terapi. Berikut ungkapan perasaan partisipan:

“....kadang terbayang ngga tumbuh lagi, kan ada katanya baru beberapa bulan dah tumbuh lagi, sempet stres juga, ya stres kalo datang lagi gimana, ...”(P1).

“...ya namanya penyakit jadi takut gitu kalo berhubungan ma suami..."(P4).

Kanker serviks bukan saja memberikan penderitaan bagi penderitanya tetapi juga orang-orang yang berada di sekitar mereka. 
Setelah terapi, beberapa partisipan menunjukkan perubahan pada interaksi dengan tetangga dan perubahan pada seksual intimasi dengan suami. Berikut kutipan wawancara:

“...saya tertutup tentang penyakit saya,jadi dilingkungan saya ngga ada yang tau saya sakit kanker, mereka taunya saya sakit biasa aja..."(P1).

“...takut jebol, takut perdarahan, emang saya ngga niat begitu-begituan (berhubungan dengan suami)...”(P3).

\section{Adaptasi untuk Mengurangi Keluhan Fisik setelah Terapi}

Seseorang akan beradaptasi terhadap perubahan yang dialami. Proses adaptasi yang dilakukan oleh partisipan pada penelitian ini berupa adaptasi untuk mengurangi disparaneu, dan mengurangi kelelahan dan mual. Berikut ini beberapa kutipan hasil wawancara dengan partisipan:

"Ya dikasi air di" barangnya suami", soalnya kan lama ngga intim, kan kering, soalnya perih, kan punya dia juga perih kalo kering...”(P2).

“...saya minum jus buah-buah apel, korma saya jus, kalo dah minum jus tuh perasaan yang tadinya mual jadi mendinga...”(P3).

\section{Harapan terhadap Kehidupan setelah Menjalani Terapi}

Terapi yang dijalani oleh partisipan akan memberikan harapan untuk tetap bertahan hidup. Harapan setelah menjalani terapi ini diungkapkan oleh sebagian besar partisipan tentang harapan terhadap penyakit yaitu keinginan untuk sembuh total dan makna hidup setelah menjalani terapi. Berikut kutipan hasil wawancara beberapa partisipan:

"Ya harapan saya jangan sakit lagi, jangan tumbuh lagi, ya mudah-mudahan harapannya nak saya ngga sakit seperti ini"(P6).

"Saya mandang hidup ngga seperti dulu, sebelum terapi kan selalu mikir apa besok saya masih bisa hidup, ngga ada harapan rasanya, tapi sekarang rasanya pengen hidup 1000 tahun lagi, inilah saya, masih bisa hidup..."(P1). “........ini ujian dari Allah, saya sabar, tegar...”(P3).

\section{Dukungan sosial}

Partisipan pada penelitian ini mendapatkan dukungan dari orang-orang sekitar seperti suami, anak, keluarga, tetangga, dan rekan kerja. Dukungan yang diberikan kepada partisipan dalam bentuk dukungan emosional, dukungan finansial, dan dukungan fisik. Berikut ini ungkapan partisipan:

\footnotetext{
"Ya itu, ngebantu biaya, dukungan, mereka semua memberi perhatian sama saya, mungkin kasian liat saya nggak ada lakinya ya, Alhamdulillah saudara pada bantu”(P7).
}

"Ya kalo suami ke rumah sakit dianterin, dia nebus obat, anakjuga sama”(P4).

\section{Persepsi terhadap Pelayanan Kesehatan yang Diperoleh}

Pelayanan kesehatan yang diperoleh partisipan saat terdiagnosa, selama, dan setelah terapi menimbulkan persepsi yang berbeda bagi partisipan. Persepsi diungkapkan partisipan, yaitu tentang sikap petugas kesehatan dan harapan terhadap pelayanan kesehatan. Berikut ini ungkapan partisipan:

"Ya dihibur, diajak becanda jadinya lebih semangat gitu, mereka ramah-ramah ngga pernah ngomel, apalagi perawat di radioterapi"'(P6).

“...perlu dijelasin, kan banyak orang yang ngga tau kayak makanan, gimana Hb biar ngga drop, kan banyak tuh yang pendiam jadi malu-malu..."(P6).

\section{Pembahasan}

\section{Berbagai Dampak setelah Menjalani Terapi Kanker Serviks}

Terapi yang diberikan pada partisipan menimbulkan efek samping dan gejala yang menyebabkan efek toksik pada sistem tubuh. Hal ini diungkapkan oleh partisipan, yaitu gangguan fungsi seksual berupa perasaan nyeri saat mulai berhubungan dengan suami dan mengalami atropi vagina. Berbagai perubahan disebabkan perubahan vaskuler pada kulit yang terkena radiasi saat pemberian brachytherapy, yaitu atropi vagina serta ada keluhan vagina menjadi kering dan nyeri saat berhubungan seksual (Otto, 2001). 
Greimel, et al. (2009) mengungkapkan hal sesuai tentang kualitas hidup dan fungsi seksual setelah terapi kanker serviks, bahwa keluhan vagina menyempit secara signifikan lebih tinggi ditemukan pada perempuan dengan radioterapi. Kemoterapi dan histerektomi juga menimbulkan dampak pada fungsi ovarium. Hilangnya fungsi hormon pada ovarium menimbulkan gejala menopause dini, seperti rasa terbakar dan kekeringan pada vagina (Frumovitz, et al., 2005; Anderson \& Lutgendorf, 1997).

Efek samping kemoterapi bervariasi tergantung pada jenis agen kemoterapi yang digunakan. Efek samping umumnya berupa mual muntah, fatigue, nyeri abdomen dan rambut rontok (Ester, 2000). Dampak fatigue ini akan menetap selama beberapa minggu atau bulan setelah radioterapi, tetapi akan menghilang secara perlahan-lahan. Hal ini disebabkan oleh adanya peningkatan metabolisme selama menjalani terapi, adanya produk toksik dari kerusakan atau kematian jaringan, kebutuhan energi untuk memperbaiki jaringan yang rusak serta dapat disebabkan oleh perjalanan menuju pelayanan kesehatan untuk menjalani radioterapi (McCorkle, et al., 1996).

Reaksi kulit diungkapkan oleh partisipan dengan radioterapi dan keluhan ini ada yang berlanjut dirasakan setelah selesai menjalani terapi. Radiasi menimbulkan dampak yang cepat pada proses peoliferasi sel dan dampak inijuga ditemukan pada folikel rambut, kelenjar keringat, dan lapisan basal epidermis (Johanson, et al., 2002; Collen \& mayer, 2006). Kanker serviks dan pengobatannya menimbulkan konsekuensi emosional yang terkait penyakit kronik. Hal ini dapat menimbulkan dampak psikologis bagi perempuan yang telah menjalani terapi kanker seviks.

McCorke, et al. (1996) mengungkapkan adanya gejala fisik akibat terapi akan mempengaruhi perubahan psikologis. Semakin berat gejala akan menyebabkan kualitas hidup berkurang dan meningkatkan gejala depresi. Pada penelitian ini diperoleh respon partisipan berupa stres dan ketakutan akan kekambuhan. Hasil penelitian ini sejalan dengan studi oleh Giwa, et al. (2006) mengungkapkan perempuan yang terdiagnosa kanker serviks mengungkapkan ketakutannya terhadap terapi, efek sampingnya, terjadinya metastasis dan kematian.

Perubahan sosial perempuan yang telah menjalani terapi dan kembali ke lingkungan masyarakat juga dihadapkan pada masalah interpersonal baik dengan suami, keluarga maupun masyarakat. Adanya efek samping setelah menjalani terapi menyebabkan gangguan body image dan merasa harga diri rendah karena malu behubungan dengan orang lain disekitarnya (Otto, 2001). Hal ini berbeda yang diungkapkan beberapa partisipan bahwa setelah menjalani terapi, mereka masih berinteraksi baik dengan tetangga.

Perubahan fungsi seksual yang dirasakan partisipan setelah menjalani terapi kanker serviks juga memberikan pengaruh terhadap hubungan dengan suami, diantaranya ada yang mulai berhubungan seksual lagi. Partisipan yang lain mengaku frekuensi lebih berkurang karena mengalami ketakutan dan tegang saat melakukan hubungan seksual dan tidak memikirkan masalah seksual. Hasil penelitian ini serupa dengan dengan yang diungkapkan oleh Anderson (2007), klien kanker melaporkan gejala disfungsi seksual yang signifikan meliputi hambatan dalam melakukan hubungan seksual dan kehilangan hasrat untuk melakukan hubungan seksual dengan pasangan.

\section{Adaptasi terhadap Perubahan setelah Terapi}

Adaptasi merupakan proses seseorang untuk berusaha menciptakan keseimbangan antara lingkungan internal dan eksternal. Salah satu penyebab stres yang berasal dari luar adalah penyakit. Partisipan pada penelitian inimengungkapkan upaya untuk mengurangi keluhan fisik, seperti mengurangi nyeri saat hubungan seksual, kelelahan, serta mual dan muntah. Beberapa partisipan mengungkapkan upaya untuk mengurangi keluhan pada organ seksual diantaranya mengubah pola seksual dengan menggunakan pelumas saat melakukan hubungan seksual dan ada yang mengatakan mencoba untuk rileks sebelum melakukan hubungan seksual untuk mengurangi nyeri saat berhubungan dengan suami. 
Jensen, et al. (2004) dalam Frumovitz, et al. (2005) mengungkapkan bahwa untuk mencegah disfungsi seksual semakin buruk selama lima tahun kedepan maka dianjurkan untuk menggunakan vagina dilator atau meningkatkan frekuensi hubungan seksual dengan pasangan setelah selesai radioterapi pada penderita kanker serviks untuk mempertahankan panjang, lebar, dan elastisitas saluran vagina.

\section{Harapan terhadap Kehidupan setelah Menjalani Terapi}

Pengalaman menjalani penyakit dan terapi selama beberapa lama akan mempengaruhi harapan penderita kanker serviks tersebut. Seluruh partisipan pada penelitian ini mengungkapkan harapan yang sama terhadap penyakitnya yaitu keinginan untuk sembuh total. Harapan dapat membantu individu untuk menghadapi penyakitnya dan menjalani kehidupannya dengan penyakit yang dideritanya melalui kehidupannya dengan penuh keteguhan (Snyder, 1994).

Hasil penelitian menunjukkan ada sikap optimisme menjalani kehidupan setelah menjalani kanker serviks dan menganggap kanker serviks sebagai anugrah sehingga dapat introspeksi diri. Beberapa partisipan yang menilai penyakit kanker serviks sebagai ujian lebih pasrah terhadap pada kehidupan yang akan dijalani dan hanya memikirkan keluarga.

Dukungan keluarga sangat mempengaruhi makna terhadap kehidupan setelah menjalani terapi. Studi yang dilakukan Mattioli, et al. (2008), penelitian tentang makna harapan dan dukungan sosial pada penderita kanker dengan kemoterapi mengungkapkan bahwa harapan mempengaruhi status kesehatan dan kesejahteraan secara keseluruhan. Dukungan dari keluarga, teman, dan petugas kesehatan sangat bernilai untuk membantu partisipan menerima penyakit dan pengobatannya.

\section{Dukungan Sosial}

Dukungan sosial sangat mempengaruhi perubahan psikolososial pada perempuan dengan kanker serviks. Keberadaan orang yang berarti dalam menghadapi diagnosis dan terapi secara signifikan dapat berpangaruh terhadap pandangan perempuan terhadap dirinya dan potensial bertahan dalam menghadapi penyakitnya. Seseorang yang mempunyai hubungan dekat dengan keluarga dan teman akan mampu menggunakan koping yang efektif(Lukbin \& Larsen, 2006).

Partisipan penelitian ini memperoleh dukungan emosional dari keluarga, terutama suami dan anakanak. Dukungan lain berasal dari tetangga dan teman dekat. Dukungan sosial dapat berupa dukungan emosional, paling besar berasal dari keluarga. Dukungan emosional dapat berupa perhatian, kasih sayang, dan doa. Adanya simpati dan perhatian dari tetangga dapat mempengaruhi pandangan perempuan terhadap kehidupannya setelah menjalani terapi (Kuntjoro, 2002).

Hasil penelitian ini sejalan yang diungkapkan oleh Giwa, et al. (2004) yang melakukan penelitian kualitatif tentang dampak kanker serviks dan dysplasia pada multietnis. Hasil penelitian ini juga mengungkapkan perempuan dengan kanker serviks dari multietnis mengungkapkan dukungan sosial yang diperoleh dari keluarga. Ibu, pasangan dan anak merupakan sumber dukungan sosial yang terbesar. Dukungan yang mereka peroleh dalam bentuk dukungan fisik, emosional, finansial, dan informasi.

\section{Persepsi terhadap Pelayanan Kesehatan}

Keberhasilan pengobatan pada penyakit kanker sangat terbatas. Hal ini menyebabkan perhatian pelayanan pada kanker bukan saja pada pengobatannya, tetapi bagaimana mengurangi efek yang behubungan dengan pengobatan dan perawatan dalam waktu yang lama. Petugas kesehatan baik perawat maupun dokter yang memberikan pelayanan kesehatan juga mempengaruhi keberhasilan terapi dan perawatan setelah menjalani terapi.

Giwa, et al. (2004) mengungkapkan sebagian besar perempuan dengan kanker serviks mengungkapkan kesulitan untuk mencari pelayanan kesehatan, pelayanan psikososial serta terbatasnya informasi tentang kanker serviks dari petugas kesehatan. 
Sejalan dengan penelitian Flanagan dan Holmes (2000) yang menemukan petugas kesehatan secara signifikan berkontribusi untuk dukungan informasi bagi penderita yang terdiagnosa kanker. Felder (2004) menungkapkan dukungan dari perawat dibutuhkan untuk menumbuhkan harapan pada penderita kanker seperti mendengarkan keluhan, bercanda dengan pasien, membangun support sistem, dan membantu pasien untuk membangun tujuan hidup yang realistis.

\section{Kesimpulan}

Terapi kanker yang telah dijalani akan menimbulkan efek samping berupa keluhan pada fisik, psikologis dan sosial. Perubahan fisik, psikologis dan sosial yang dialami oleh perempuan setelah menjalani terapi kanker serviks mendorong partisipan melakukan adaptasi untuk mengatasi berbagai keluhan tersebut. Adaptasi yang dilakukan oleh partisipan pada penelitian ini adalah adaptasi terhadap perubahan fungsi seksual yaitu untuk mengurangi disparaneu.

Semua partisipan pada penelitian ini mempunyai harapan yang sama terhadap penyakit yaitu keinginan mereka untuk sembuh total. Dukungan sosial juga sangat mempengaruhi perubahan fisik dan respon psikososial pada perempuan yang telah menjalani terapi kanker serviks. Pelayanan yang diperoleh oleh partisipan selama dan setelah menjalani terapi kanker serviks memberikan persepsi yang berbeda tentang sikap petugas kesehatan dan harapan terhadap petugas kesehatan.

Partisipan dalam penelitian berharap mendapat dukungan emosional dari petugas kesehatan dan kebutuhan informasi tentang penyakit dan terapi. Perawat diharapkan memberikan dukungan dari baik itu dukungan emosional dan informasi untuk meningkatkan semangat dan harapan perempuan setelah menjalani terapi kanker serviks (AT, YR, YA).

\section{Referensi}

Anderson, B., \& Lutgendorf, S. (1997). Quality of life in gynecologic cancer survivors. Cancer journal for clinicians, 47, 218-225.
Bahaya kanker serviks bagi wanita. (2009). Kesrepro. Diperoleh dari http://www. kesrepro.info/?q= node $/ 380$.

Castilaw, D., \& Wittet, S. (2007). Preventing cervical cancer: Unprecedented opportunities for improving women's health. Outlook Program for Appropriate Technology in Health (PATH), $23(1), 1-12$.

Clemens, Knafl, Lev, \& McCorkle. (2008). Cervical cancer: Patterns of long-ter survival. Onclogy Nursing Forum, 35 (6).

Ester. (2000). Rencana asuhan keperawatan onkologi. Jakarta: EGC.

Felder, B. E. (2004). Hope and coping in patients with cancer diagnoses. Cancer Nursing, 27 (4), 320324.

Feldman, S. (2003). How often should we screen for cervical cancer? New England Journal of Medicine, 349 (16), 1495-1496.

Flanagan, J., \& Holmes, S. (2000). Social perceptions of cancer and their impacts: Implications for nursing practice arising from the literatur. Journal of Advanced Nursing, 32 (3), 740749.

Frumovitz, et al.(2005). Quality of life and sexual functioning in cervicalcancer survivors. Journal of Clinical Oncology, 23 (30), 7428.

Giwa, et al. (2004). The Impact of cervical cancer and dysplasia: A qualitative, multiethnic study. Psychooncolog, 13 (10).

Greimel, et al. (2009). Quality of life and sexual functioning after cervical cancer treatment: a longterm follow-up study. Psycho-Oncology, 18, 476-482.

Jensen, P.T., et al. (2004). Longitudinal study of sexual function and vaginal changes after radiotherapy for cervical cancer. International Journal Gynecology Cancer, 100, 97-106.

Johansson, S., Svensson, H., \& Denenkamp, J. (2002). Dose response and latency for radiation induced fibrosis, edema and neuropathy in breast cancer patients. International Journal Radiattherapy Oncology Bio Phys, 52, 1207-1219. 
Kuntjoro, S.Z. (2002). Dukungan sosial pada lansia. Diperoleh dari http://www.e-psikologi.com/ epsi/artikel.

Otto, S.E. (2001). Oncology nursing reference (4th Ed.). St. Louis: Mosby.
Snyder, C.R. (1994). The psychology of hope: You can get there from here. New York: Free press.

Streubert, H.J., \& Carpenter, D.R. (1999). Qualitative research in nursing: Advancing the humanistic imperative (2nd Ed.). Philadelphia: Lippincott.

Berusahalah untuk tidak menjadi manusia yang berhasil, tapi berusahalah menjadi manusia yang berguna.

- Einstein -

Contoh yang baik adalah nasihat terbaik.

- Fuller -

Kita semua hidup dalam ketegangan, dari waktu ke waktu, serta dari hari ke hari; dengan kata lain, kita adalah pahlawan dari cerita kita sendiri.

- Mary Mccarthy -

Tiga sifat manusia yang merusak adalah, kikir yang dituruti, hawa nafsu yang diikuti, serta sifat mengagumi diri sendiri yang berlebihan.

- Nabi Muhammad Saw -

Seseorang yang melihat kebaikan dalam berbagai hal berarti memiliki pikiran yang baik.

Dan seseorang yang memiliki pikiran yang baik mendapatkan kenikmatan dari hidup.

- Bediuzzaman Said Nursi -

Pengetahuan tidaklah cukup; kita harus mengamalkannya.

Niat tidaklah cukup; kita harus melakukannya.

- Johann Wolfgang von Goethe - 